\title{
Context in English Language Teaching Program: Differentiating between Iranian Public Schools and Private Institutes
}

\author{
Hooshang Khoshsima, Ph.D. Associate Professor \\ Chabahar Maritime University, Chabahar, Iran \\ Khoshsima2002@yahoo.com \\ Seyyed Morteza Hashemi Toroujeni, M.A. Candidate \\ Chabahar Maritime University, Chabahar, Iran \\ Hashemi.seyyedmorteza@gmail.com \\ M.hashemi@cmu.ac.ir
}

\begin{abstract}
For some years, there was a debate about the effectiveness of public and private sectors in language learning field, not only in Iran but also in USA and Europe. Actually, a context in which language learners are provided with friendly communicative environment is a great help to learn how to use the language communicatively in authentic situations. Therefore, a context in which the efficient factors are employed more appropriately enables EFL learners to emphasize the communicative use of language in everyday, real world situations. In Iran, the students can learn English in two contexts including a) public schools that are funded and supported by the government b) private institutes. In public education, the students start learning English from the first year of Junior Secondary Program for six years. But after graduating from high school, hardly some of them are able to communicate fluently (Safari \& Rashidi, 2015). Thus, this study investigated the comparability of the effectiveness of two education systems applied in two contexts on oral communication skills. Direct observations, interviews, and FCE speaking
\end{abstract}


test taken by 154 students of two contexts revealed that the language learners of private institutes outperformed on oral skills. Furthermore, the results of independent $t$-test indicated that 8 internal and external moderator-factors assessed by a questionnaire might affect speaking performance of language learners in two contexts. The findings were also supported by the interview-based data.

Keywords: Context in TEFL; Oral Proficiency; Public School; Private Language Institutes

\section{INTRODUCTION}

English is dramatically strengthening its position as the most powerful international communication language (Zare Behtash \& Hashemi Toroujeni, 2017). Since the society has a tendency to make speaking skill as a measure of one's mastery of English (Nazara, 2011), in today's competitive world, people want to improve the efficient skills to convey their messages in a thoughtful and convincing manner to communicate their ideas, concepts, ideologies, scientific and technological findings successfully. According to Burns and Joyce (1997), speaking is an interactive process of constructing meaning which involves receiving, processing, and producing information. Forms and meanings in speaking are related to each other and also interpreted based on the context in which it happens. The learning context includes physical environment, purposes for speaking and other factors that make it possible to speak a language correctly. According to Hughes, the basically temporary articulated words to establish direct communications are uttered within a context in which coordination between a particular place and a particular moment is met (Hughes, 2011). A communicative context, in which a wider and more appropriate variety of materials, activities, instructors and student groupings are applied, according to Taylor (1983), encourages learners to exercise their own initiative in communicating (p. 69) and consequently, communication takes place comfortably (p. 70). Therefore, a suitable context in which the effective factors and variables are employed more appropriately enables EFL/ESL learners to learn how to communicate in the target language fluently and freely and to emphasize the communicative use of language in authentic situations (Abu-Ghararah, 1998, p. 5).

According to Brown and Yule (1983), the oral proficiency is regarded as the criteria of mastering a language. They add that the learners' making good progress with the language is evaluated in terms of success in spoken communication. Expanding English as the working language in $85 \%$ of international organizations (Crystal 2003) and as an opportunity to get better jobs have motivated Iranian students to learn it as the international and active language of internet, science and technology for the cross-cultural purposes. Iranian students learn English language in two contexts: a) public schools that is compulsory for students from the first year 
of Junior Secondary Program in high school (Junior Secondary Program is a phase of education in public school for years $6,7,8$ and 9, and b) and private language institutes which are not operated by the government, but depending on their location, private institutes may be subject to government regulation.

Although the students of public schools start learning English from the first year of Junior Secondary Program in high school that lasted six years, hardly some of them make a practical use of language in real contexts (Safari \& Rashidi, 2015) after graduating. A few comparability studies have been conducted on the differences in the effectiveness of public education system and private sector in teaching English language especially in oral communication skill. The lack of study on this issue may be due to the dominance and nation-state orientation of public education system especially in developing countries (Dronkers, 2001).

We can compare two systems based on physical environments, teachers, age and background knowledge of the learners, methodologies, books, materials and technological tools. The English textbooks of public educational system are planned by the authors that are affiliated with the Ministry of Education (Dahmardeh, 2009). These textbooks introduce letters and sounds of alphabet, basic sets of vocabulary items, reading comprehension texts and writing exercises in lower educational levels. In higher educational levels, longer reading comprehension passages and vocabulary and grammar practices are given. Totally, minor modifications and amendments are made to the textbooks' content and structure employed in public education system (Sharabian et al, 2013).

\section{LITERATURE REVIEW}

According to Kavaliauskienè (2006), language is a tool for people to convey their identity in society. Today, the purpose of L2 learning inside the classroom is to achieve the ability of using the language outside the classroom. So, among different subjects in L2 instructional domain, some significant critical issues such as speaking skill, the context in which the students' creativity is motivated (Khoshsima et al., 2015) and the effect of the context on speaking performance attracted the attention of many language practitioners. The researchers weigh up certain problems such as how basic language skills including listening, speaking, reading, and writing are developed within language learners in different contexts and how various contexts with their own features and characteristics influence the learning process within language learners.

The importance of speaking skill in EFL classrooms necessitates finding and using the best requirements for an ideal context (Khoshsima \& Hashemi Toroujeni, 2017) such as instructional methods, materials, activities, media, and other requirements to help language learners master speaking skill (Hashemi Toroujeni, 2016). In spite of conducting a large number of studies to assist learners to master speaking skill, many EFL learners still find learning speaking skill very difficult to master. Cotter (2007) expresses that practicing the oral skill lets learners to interact in meaningful ways such as exchanging information, negotiating meaning, supporting ideas, or facing oral defenses. This means that working on the oral production gives learners the opportunities of rehearsal to strengthen their ability to 
communicate a set of ideas in a range of different situations. Burns and Joyce (1997) claim that if the main aim of language programs is to prepare students to use spoken language effectively in social situations, then teachers need to present students with authentic spoken texts in the classroom (p. 85). The contexts in which the texts and materials are used for communication should be carefully considered.

Ellis (1996) presents three main reasons to make learners speak in the classroom. First, the author states that using speaking activities gives learners the chance to practice the real life oral production in the classroom. Second, the practice of the oral skill in the classroom through speaking activities provides feedback of the use of the language for learners and teacher. Finally, with the practice of oral interaction in the classroom, students have the opportunity to use the language that they have learnt. Then, through this process learners and teacher can enhance their oral production.

English is taught in public schools and private institutes with different conditions that result in various levels of effectiveness for both educational systems. Some research on the differences of effectiveness between public schools and private institutes (Scheerens \& Bosker, 1997; Teddlie \& Reynolds, 2000) were conducted. Public schools and private institutes vary in their characteristics, conditions, and administrations for teaching and learning. These variations in their educational administrations may influence the effectiveness and educational performance (Hofman, 1993). Existence of possible differences in social composition of the population, different needs and expectations in public schools and private institutes, differences in administrations and conditions of teaching and learning, and other observable distinctions between public schools and private institutes might lead to various behavioral patterns from students and teachers. Consequently, these various behavioral patterns and other variables will determine the most appropriate educational system and its components, norms of instruction and the relations between teachers and learners that will absolutely affect the effectiveness of teaching and learning within these two different learning contexts.

Atai and Mazlum (2013) declare that the process of deciding new policies in the current ELT curriculum of Iranian public education system is highly centralized, and no policy is made by policy makers in the local levels. In the Secondary education, English is presented at the first year of high school in the current Iranian public education system (Ghorbani, 2009). The number of students who want to learn a second or foreign language in private institutes is increasing all the time in Iran.

The issue of context is a very crucial issue in language learning and teaching. According to Brown (2000), virtually any complex set of skills brings with it a host of questions which can turn into issues. Brown (2000) enumerates these issues and sorts them into some commonly used topical categories. The categories include learner characteristics, linguistic factors, learning processes, age and acquisition, instructional variables, context and purpose. An appropriate context in which a wider variety of materials, activities, and student groupings are applied, according to Taylor (1983), requires an atmosphere which "encourages learners to exercise their own initiative in communicating" (p. 69) and "in which communication can take 
place comfortably" (p. 70). Therefore, its primary goal is to "enable EFL learners to communicate in the target language fluently and freely and to emphasize the communicative use of language in everyday, real world situations (Abu-Ghararah, 1998, p. 5).

Several studies have revealed the effects of communicative contexts on students' oral proficiency. As an example, Gutierrez (2005) observed the role of teachers and students during development of oral tasks. He found out that his students attained proficiency in language use in the context where they could speak fluently through asking and giving information and supporting their ideas (p. 7). The findings of a comparability study conducted by Alam \& Uddin (2013) in Karachi showed that the practice of teaching language required changing in the context of second language learning. The teacher-centered classrooms should be changed with student-centered classes and learner-learner interaction. The traditional methods of teaching should be replaced with modern methods such as communicative approach and task-based teaching approaches. Due to the lack of social interaction in EFL context which naturally occurs in an ESL context, Bahrani \& Shu Sim (2012) investigated language learning in outside of the classroom (informal context). To explore which source of language input would have a greater effect on learning, their study investigated the effect of exposure on speaking proficiency. In the study, two kinds of exposures including audiovisual mass media and social interaction were provided as input source for the EFL context and input source for the ESL context, respectively. The findings showed that EFL group outperformed which was indicative of the fact that exposure to technology in informal context promotes speaking proficiency. Pishghadam \& Saboori (2011) studied the assorted ways Iranian language learners viewed their language educational system and the effect of the views on their learning a foreign language based on metaphors stated by the learners. Their findings showed that the students of public schools mostly assign the 'behavioristic' methods as the reason of their failure in language learning; while language learners attribute their apparent success to the 'cognitive' style of learning applied in private institutes.

Both quantitative and qualitative data were gathered to answer the research question. In this study, neither experimental nor control group were defined. In order to answer the research questions, the researcher collected data qualitatively and analyzed it quantitatively from the transcriptions of learners' oral performance. As Nunan and Bailey (2009) mentioned, qualitative data in second language classroom research can take many forms such as video or audio recording of classroom interaction (p. 413).

\section{RESEARCH METHOD}

\subsection{Sample}

In this study, both male and female participants were 899 students of 13 public schools and 450 language learners of 8 private institutes which were randomly selected from Sari, Rasht, Gorgan, Behshahr, and Chabahar cities. All the pre-university level students of public schools who were majoring in different subjects have received the similar and the same amount of exposure during 6 years 
of Junior Secondary Program. They had the same level of proficiency because all the students who were taking additional classes in private institutes were excluded from this group; in fact, they have studied and learned English language just in public schools. All the participants as pre-university (the last year of Junior Secondary Program) students of high schools received the same amount of instruction time i.e. two sessions every week, each session lasted 75 minutes for nearly 18 sessions. The ages of both male and female public schools' students mainly ranged from 17 to 19 . Their mean age was 18. The participants from public schools were assigned into one group. The other research group consisted of 450 language learners of private institutes. The age range of all the 450 students who had signed the consent form to participate in the study was between 14 to 25 years. And, the mean age was 17.5 . All the participants of this group received the same amount of instruction time i.e. three sessions every week, each session lasted 90 minutes for nearly 22 sessions.

Table 1. Frequency distribution of samples from public schools and private institutes

\begin{tabular}{|c|c|c|c|c|c|c|c|}
\hline & \multirow{2}{*}{$\begin{array}{l}\text { Student } \\
\text { s of } \\
\text { public } \\
\text { schools }\end{array}$} & \multirow{2}{*}{$\begin{array}{c}\text { Randoml } \\
\text { y selected } \\
\text { students } \\
\text { to take } \\
\text { the } \\
\text { Nelson } \\
\text { Test }\end{array}$} & \multirow{2}{*}{$\begin{array}{l}\text { Randomly } \\
\text { selected } \\
\text { students } \\
\text { to } \\
\text { participat } \\
\text { e in } \\
\text { speaking } \\
\text { test }\end{array}$} & \multirow{2}{*}{$\begin{array}{l}\text { Languag } \\
\text { e learners } \\
\text { of private } \\
\text { institutes }\end{array}$} & \multirow{2}{*}{$\begin{array}{c}\text { Randomly } \\
\text { selected } \\
\text { language } \\
\text { learners to } \\
\text { participat } \\
\text { e in } \\
\text { speaking } \\
\text { test }\end{array}$} & \multicolumn{2}{|c|}{$\begin{array}{c}\text { Number of } \\
\text { students to answer } \\
\text { the questionnaire }\end{array}$} \\
\hline & & & & & & $\begin{array}{c}\text { Public } \\
\text { school } \\
\text { S }\end{array}$ & $\begin{array}{c}\text { Private } \\
\text { institute } \\
\mathrm{s}\end{array}$ \\
\hline Behshahr & 310 & 96 & 23 & 160 & 26 & 310 & 160 \\
\hline $\begin{array}{l}\text { Chabaha } \\
\text { r }\end{array}$ & 92 & 25 & 15 & 60 & 8 & 92 & 60 \\
\hline Sari & 168 & 68 & 13 & 58 & 15 & 168 & 58 \\
\hline Rasht & 119 & 33 & 8 & 96 & 12 & 119 & 96 \\
\hline Gorgan & 210 & 56 & 18 & 76 & 16 & 210 & 76 \\
\hline $\begin{array}{l}\text { Total } \\
\text { number }\end{array}$ & 899 & 278 & 77 & 450 & 77 & 899 & 450 \\
\hline
\end{tabular}

\subsection{Instruments}

Choosing appropriate research data collection instruments is necessary for every researcher because utilizing proper and applicable instruments make collecting precise research data possible (Warner, 2013). The researcher of the present study employed the following instruments to collect the required data to achieve the research goals.

The classroom observation was carried out in both contexts to see if teachers and students practiced the principles of defined syllabus and curriculum while the actual class lesson was going on. Merriam (2002) explains that observational data represent a firsthand encounter with a phenomenon of interest rather than a second hand account obtained in an interview (p. 1). In order to meet the objectives of the observation, an observation checklist as well as assessment rubric (based on defined syllabuses and approaches for both contexts) was developed and employed. The two instruments were submitted to the panels of jury to determine their validity and 
appropriateness of the approaches needed to be applied in the classrooms. The observations were made based on checklists which focused on classroom instructional activities or techniques employed by teachers, the role teachers and learners played and instructional materials used in the teaching-learning process. After ensuring that the teachers used appropriate approaches based on the syllabus or curriculum defined for each context, Nelson Proficiency Test (test $150 \mathrm{C}$, appendix A) which was selected from Nelson English Language Tests by Fowler and Coe (1976) was administered to 278 randomly selected students of public schools to determine their proficiency level and homogeneity.

The speaking performance cannot be easily assessed and the candidate's speech should be assessed with closer scrutiny by experts (Khoshsima et al., 2015b). Since most results obtained from the assessment of speaking performance are not reliable and consistent if global or holistic marks are given, Cambridge ESOL examination package which provides an exact analytical assessment criterion to candidates marking was used in the present research. In this examination package, speaking is the $5^{\text {th }}$ paper (in the order of papers including reading, writing, and use of English, listening and speaking). The test which was administered to two candidates at the same time lasted for about 14 minutes in the current study. The speaking test, based on the ESOL package, consisted of four parts including 1) interview that lasted approximately 3 minutes. It was a conversation between interlocutor and candidate who should express himself clearly and give information about past experiences, present circumstances and future plans, 2) long turn in which the task lasted approximately 4 minutes. Here, each candidate was given a pair of photographs to talk about by organizing larger units of discourse by comparing and contrasting the photos and expressing opinions, 3) collaborative task that lasted approximately 3 minutes. In the collaborative task, the learners were supposed to show their ability to exchange information, express and justify opinions, speculate and reach a decision, 4) and discussion that lasted approximately 4 minutes.

The 32-item questionnaire based on 5-point Likert scale was designed to inquire about students' perceptions on variables relating to the effectiveness of two educational systems to develop their oral skills throughout the course based on the data attained from interviews. The semi-structured questions of the interview protocol were used to elicit and inquire about 58 teacher's opinions and experiences related to their teaching and learning in class. These interviews were done to derive the final variables that might influence the oral ability of students in two contexts.

The first part of the questionnaire elicits demographic information of participants including name, age, level of education and etc. The second and the main section of the questionnaire consisted mainly of 32 statements to gauge the learners' perceptions of language learning in the classroom. The items were developed based on the past research and also the interviews with competent teachers and experts. The questionnaire statements were categorized under 8 variables including methodology, book, teacher, instructional environment, time, age, motivation, and need. The content of the questionnaire was face and content validated by three experts in the field of TEFL. In order to check the internal consistency of the questionnaire results, a pilot study was conducted. The 
participants involved in the pilot study were not included in the main research. The reliability of the questionnaire instrument was tested by Cronbach's alpha coefficient. The fabricated questionnaire was distributed to the pilot group of 173 (93 students of public schools and 80 language learners of private institutes) randomly selected students from a public school and a private institute. High Cronbach's reliability coefficients $(\alpha=.93)$ and $(\alpha=.91)$ were obtained for the internal consistency of the questionnaires distributed to the students of public schools and private institutes, respectively.

\subsection{Procedure}

The process of data collection for this study was done during autumn 2016 . First, some direct observations of the classrooms have been done by the researcher to get an idea of what is done exactly in both public and private schools. In order to meet the objectives of the observation, an observation checklist as well as the assessment rubric of approaches' principles was developed and employed. The two instruments were submitted to the school and institute's panel of jury to determine their validity and appropriateness of the skills based on the designed syllabus needed to be applied in the classroom setting. In the next stage, due to the large sample size, Nelson Proficiency Test was administered to 278 randomly selected students of public schools to the purpose of checking their homogeneity.

All the students of public schools as pre-university (the last year of Junior Secondary Program) students of high schools received the same amount of instruction time i.e. two sessions every week, each session lasted 75 minutes for nearly 18 sessions. Although, they received the same amount of English exposure in schools, 278 students were randomly selected from public educational system to be evaluated in terms of their language proficiency. The Nelson Proficiency Test included fifty multiple-choice questions to assess the lexical, grammatical and phonological knowledge of the participants. Generally, the Nelson English Language Test consists of 40 separate tests for ten levels of language proficiency ranging from beginners to the advanced. It is worth mentioning that the $30(60 \%)$ pass mark is considered for the tests. The students of public schools were asked to do the Nelson placement test in 45 minutes. The participants, who answered at least $60 \%$ of questions (30 questions out of 50) correctly, were confirmed to be at the desired level of proficiency. According to the results of Nelson Test, all the students of public schools were approximately at the intermediate level. It is worth mentioning that in the sample selection process of private institutes, the researcher trusted the language institutes' common policy. In fact, the newcomers who enroll at private language institutes take a placement test to be placed in different level classes. At the end of each course, language learners pass a final exam to enter the next level. Accordingly, both the intermediate students of public schools selected by implementing placement test and the intermediate language learners of private institutes who were placed in the level by the institute's common policy were assigned to two testing groups that were supposed to take the speaking test.

After that, FCE speaking test of ESOL examination package was implemented in both public schools and private language institutes to find out 
whether there was any significant difference between oral proficiency of intermediate students of both contexts. Due to the large sample size and lack of facilities, 77 intermediate candidates from each context were randomly selected from among those who took placement test. They were invited to participate in the speaking test. It was done by the help of four colleagues of mine. The researcher awarded three scores to the candidates of each context. First, candidates were given a global mark by the interlocutor during the test. Second, simultaneously one assistant professor proficient at teaching gave an analytical score based on the ESOL assessment criteria. In the last place, the researcher awarded analytical score based on Hughes (2003) speaking assessment criteria by analyzing recorded voice of the candidate. Then, in order to achieve a high interrater reliability of test scores given by the raters who were unaware of the expected outcomes of the study, a bivariate correlation analysis was conducted. According to the Table 2, correlation was significant at the 0.01 level and it could be concluded that there was a relative positive correlation between the scores obtained from public schools assigned by the raters. Hence, the scores obtained by the raters were to be consistent.

Table 2. Inter-rater reliability of scores obtained from public schools

\begin{tabular}{|c|c|c|c|c|c|c|c|}
\hline \multicolumn{2}{|r|}{ Correlations } & \multicolumn{3}{|c|}{ Public schools } & \multicolumn{3}{|c|}{ Private institutes } \\
\hline Rater1 & $\begin{array}{l}\text { Pearson Correlation } \\
\text { Sig. (2-tailed) } \\
\text { N }\end{array}$ & $\begin{array}{r}1 \\
77\end{array}$ & $\begin{array}{r}.622^{* *} \\
.002 \\
77\end{array}$ & $\begin{array}{r}.744^{* *} \\
.000 \\
77\end{array}$ & 1 & $\begin{array}{r}.832^{* *} \\
.001 \\
77\end{array}$ & $\begin{array}{r}.934^{* *} \\
.000 \\
77\end{array}$ \\
\hline Rater2 & $\begin{array}{l}\text { Pearson Correlation } \\
\text { Sig. (2-tailed) } \\
\text { N }\end{array}$ & $\begin{array}{r}.622^{* *} \\
.002 \\
77\end{array}$ & 77 & $\begin{array}{r}.509^{* *} \\
.003 \\
77\end{array}$ & $\begin{array}{r}.832^{* *} \\
.001 \\
77\end{array}$ & $\begin{array}{r}1 \\
77\end{array}$ & $\begin{array}{r}.810^{* * *} \\
.002 \\
77\end{array}$ \\
\hline Rater3 & $\begin{array}{l}\text { Pearson Correlation } \\
\text { Sig. (2-tailed) } \\
\text { N }\end{array}$ & $\begin{array}{r}.744^{* *} \\
.000 \\
77\end{array}$ & $\begin{array}{r}.509^{* *} \\
.003 \\
77\end{array}$ & 77 & $\begin{array}{r}.934^{* * *} \\
.000 \\
77\end{array}$ & $\begin{array}{r}.810^{* *} \\
.002 \\
77\end{array}$ & 77 \\
\hline
\end{tabular}

Pearson's Product-Moment Correlation Coefficient to analyze data obtained from public schools indicated that the correlation between the first and second rater was significant at 0.01 level $(r=0.622, \mathrm{p}<0.01,0.002<0.01)$. Consequently, regarding the first and third raters, the $\mathrm{p}$ value was also less than 0.01 level $(\mathrm{r}=$ $0.744,0.00<0.01)$. At last, concerning the second and third raters there was also a significant relationship between the two scores $(r=0.509,0.003<0.01)$. Furthermore, analyzing the data received from private institutes showed that the correlation between the first and second rater was significant at 0.01 level $(\mathrm{r}=0.832$, $\mathrm{p}<0.01,0.001<0.01)$. Consequently, regarding the first and third raters, the $\mathrm{p}$ value was also less than 0.01 level $(r=0.934,0.00<0.01)$. Regarding to the second and third raters, there was also a significant relationship between the two scores $(\mathrm{r}=$ 
$0.810,0.002<0.01)$. Then, according to the results, it could be concluded that the scores of the students of public schools given by the three raters were to be reliable.

In the next stage, 33 teachers of public schools and 25 of private institutes with more than 10 years of teaching experiences were invited to be interviewed to elicit their opinions and experiences related to teaching. Based on the interviews, final variables that might influence the effectiveness of public schools and private institutes in developing oral proficiency of students were derived. The teachers were selected on the basis of stratified purposeful sampling which is a commonly used sampling method in qualitative research (Ary, Jacob, \& Sorenson, 2010) and lends credibility to the research study. The researcher brought the sampling process to a stop when the required saturation that is an essential stage to ensure the sufficiency of collected data was attained and no new research data and information was achieved. The interview contained some open-ended questions to detect various characteristics and variables of public schools and private institutes that resulted in different effectiveness levels in oral proficiency of language learners. Then, it should be mentioned that the questionnaire the 899 students of public schools and 450 language learners of private schools were given to respond was based on the information of interviews provided in advance.

\section{RESULTS AND DISCUSSION}

To provide reasonable answers to the research question, descriptive statistics as well as independent sample t-test was utilized to analyze participants' responses in this survey by the use of SPSS software.

Before that, Shapiro-Wilks and Kolmogorov-Smirnov statistical tests were used to provide objective judgement of data distribution normality. Anyway, the result of normality testing is displayed in Table 3 statistically.

Table 3. Normality distribution test for speaking test scores

\begin{tabular}{|c|c|c|c|c|c|c|}
\hline \multicolumn{7}{|c|}{ Tests of Normality } \\
\hline & \multicolumn{3}{|c|}{ Kolmogorov-Smirnov $^{a}$} & \multicolumn{3}{|c|}{ Shapiro-Wilk } \\
\hline & Statistic & D.F. & Sig. & Statistic & D.F. & Sig. \\
\hline $\begin{array}{l}\text { Scores received from public } \\
\text { schools }\end{array}$ & .184 & 77 & .887 & .832 & 77 & .738 \\
\hline $\begin{array}{l}\text { Scores received from public } \\
\text { schools }\end{array}$ & .171 & 77 & .804 & .804 & 77 & .791 \\
\hline
\end{tabular}

From Table 3, it was concluded that the data received from speaking tests implemented in two contexts were normally distributed.

We continued data analysis by conducting independent $t$-test. The main goal of t-test series conducted in this section was to examine if there was any statistically significant difference in participants' speaking performance across two public school and private institute contexts. First, descriptive statistics (Table 4) were used to gain a better view of the data, and then the inferential statistics (Table 5) analysis was displayed to find out the relationship between mean scores. 
Table 4. Descriptive Statistics of both groups speaking tests

\begin{tabular}{llcccc}
\hline & Mean & $\mathbf{N}$ & $\begin{array}{c}\text { Std. } \\
\text { Deviation }\end{array}$ & $\begin{array}{c}\text { Std. Error } \\
\text { Mean }\end{array}$ \\
\hline $\begin{array}{l}\text { Speaking } \\
\text { performance }\end{array}$ & $\begin{array}{l}\text { Public } \\
\text { schools } \\
\text { Private } \\
\text { schools }\end{array}$ & $\mathbf{4 4 . 8 8}$ & 77 & $\mathbf{1 7 . 1 8}$ & 1.95 \\
& & $\mathbf{5 6 . 3 5}$ & 77 & $\mathbf{1 8 . 2 0}$ & 2.07 \\
\hline
\end{tabular}

As displayed in Table 4, the mean score of public schools on speaking performance $(\mathrm{M}=44.88, \mathrm{SD}=17.18)$ was lower than that of private institutes $(\mathrm{M}=$ $56.35, \mathrm{SD}=18.20$ ) (Table 4). Then, between two speaking performance, the highest mean score was found in testing group of private institutes $(M=56.35)$ compared to the testing group of public schools, with a relatively higher mean score by 11 points.

Table 5. Independent sample t-test on speaking tests

\begin{tabular}{|c|c|c|c|c|c|c|c|c|c|}
\hline & \multicolumn{2}{|c|}{$\begin{array}{l}\text { Equality of } \\
\text { Variances }\end{array}$} & \multicolumn{7}{|c|}{ t-test for Equality of means } \\
\hline & \multirow[t]{2}{*}{$\mathrm{F}$} & \multirow[t]{2}{*}{ Sig. } & \multirow[t]{2}{*}{$\mathrm{t}$} & \multirow[t]{2}{*}{$\overline{\mathrm{df}}$} & \multirow[t]{2}{*}{$\begin{array}{l}\text { Sig. } \\
(2- \\
\text { tailed })\end{array}$} & \multirow[t]{2}{*}{$\begin{array}{c}\text { Mean } \\
\text { difference }\end{array}$} & \multirow[t]{2}{*}{$\begin{array}{l}\text { Std. Error } \\
\text { Difference }\end{array}$} & \multicolumn{2}{|c|}{$\begin{array}{l}\text { 95\% Confidence } \\
\text { Interval of the } \\
\text { Difference }\end{array}$} \\
\hline & & & & & & & & Lower & Upper \\
\hline $\begin{array}{c}\text { Equal } \\
\text { variances } \\
\text { assumed }\end{array}$ & .283 & .596 & -4.01 & 152 & .000 & -11.46 & .2 .85 & -17.10 & -5.82 \\
\hline $\begin{array}{c}\text { Equal } \\
\text { variances } \\
\text { not } \\
\text { assumed }\end{array}$ & & & -4.01 & 151.4 & .000 & -11.46 & 2.85 & -17.10 & -5.82 \\
\hline
\end{tabular}

To answer the main question of the research that looks for the significance difference between the testing scores obtained from two contexts, independent sample t-test was conducted. All statistical analyses that were reported in the present research were done with a significant level of .05 . Then, according to the findings (Table 5), there was a statistically significant difference in testing scores received from public schools and private institutes at a .05 level.

Therefore, independent sample t-test rejected the null hypothesis that there was no statistically significant difference in the results of speaking tests administered to the students of public schools and language learners of private institutes. Based on the results of the score analysis of two testing sessions, the Sig. value was .000 at $\mathrm{P}<0.05$. This amount of significance value at $152(\mathrm{~N}-2)$ degree of freedom in a .05 level revealed that there was a statistically significant difference between two sets of speaking scores obtained from two contexts and the speaking test scores of participants obtained from the contexts of public schools and private institutes were different $(\mathrm{Sig}=.000, \mathrm{P}>0.05)$. Therefore, independent sample t-test 
analysis showed that the differences between the speaking test scores of public school context $(n=377, M=44.88, S D=17.18)$ and speaking test scores of private institutes context $(n=77, M=56.35 .13, S D=18.20)$ were statistically significant, Sig $=.000, \mathrm{p}>0.05$.

This study was an attempt to investigate the effect of two separate contexts and the key related factors on English language learning process of students of both public schools and private language institutes. For such a purpose, the answers of two groups of students to the researcher-made questionnaire including 32 statements regarding 8 variables including methodology, book, teacher, instructional environment, time, age, motivation, and need were analyzed using statistical independent t-test. Both descriptive and inferential statistics for each variable were provided in separate tables. An inspection of the mean scores and other results showed that there was a considerable difference between two education systems in terms of 8 external and internal moderator-variables. Moreover, the independentsamples t-test analysis showed that the differences between most of the variables were statistically significant $(\mathrm{p}<0.05)$.

Tables $6 \& 6.1$ display the results of the independent sample t-test for the "methodology" applied in both public schools and private institutes. From Tables 6, it can be concluded that the mean for methodology applied in private institutes $(M=2.05)$ is higher than the mean for methodology applied in public schools $(M=1.81)$. It means that the methods employed to teach English in private institutes are more efficient. Consequently, according to the Table 6.1, the p-value is less than $0.05(0.004>0.05)$ which indicates that there is a statistically significant difference between the effectiveness of methodology applied in two different contexts. As a result, it can be consummated that the two methodologies were not relatively at the same level of effectiveness in two contexts. It displayed that methodology is considered as one of the most effective variable in EFL/ESL context to help language learners improve their oral ability. On that account, any incongruity between the speaking performance of two groups from public schools and private institutes may be attributed to the kind of method used in the classrooms.

Therefore, the significant difference $(\mathrm{P}=0.004<0.05)$ that were found between the methodologies used in two contexts suggests that methodology might create a significant change on the behavior of the learners in language proficiency development.

Table 6. Descriptive statistics of "methodology" variable in public schools \& private institutes

\begin{tabular}{lcccc}
\hline & $\begin{array}{c}\text { total } \\
\text { number }\end{array}$ & mean & $\begin{array}{c}\text { standard deviation } \\
\text { mean }\end{array}$ & $\begin{array}{c}\text { standard } \\
\text { deviation }\end{array}$ \\
\hline Private institutes & 450 & 2.05 & .042 & .461 \\
\hline Public schools & 889 & 1.81 & .070 & .467 \\
\hline
\end{tabular}


Table 6.1. Independent t-test results

\begin{tabular}{ccccccc}
\hline $\mathrm{F}$ & Sig & $\mathrm{t}$ & $\begin{array}{l}\text { degree of } \\
\text { freedom }\end{array}$ & Sig. (2-tailed) & $\begin{array}{c}\text { mean } \\
\text { difference }\end{array}$ & $\begin{array}{c}\text { standard } \\
\text { error }\end{array}$ \\
mean & & & & & & \\
\hline .068 & .795 & 2.892 & 1337 & $\mathbf{. 0 0 4}$ & .234 & .081 \\
\hline
\end{tabular}

According to Table 7, it can be concluded that the mean for "teacher" employed in private institutes $(M=2.70)$ is higher than the mean for teacher employed in in public schools $(\mathrm{M}=1.90)$. It means that the teachers that are employed to teach English in private institutes are more competent in teaching process. Therefore, independent sample t-test analysis (Table 7.1) shows that the difference between two public schools $(n=889, M=1.90, S D=0.102)$ and private institutes $(n=450, M=2.70, S D=.087)$ contexts, in terms of teacher, is statistically significant, Sig $=.000, \mathrm{p}>0.05$. Then, according to the results, any incongruity between the effectiveness of two contexts may be attributed to the qualified teachers employed to teach English in two contexts.

Table 7. Descriptive statistics of "teacher" variable in public schools \& private institutes

\begin{tabular}{lccc}
\hline standard & total & mean & standard deviation \\
& number & & mean \\
deviation & & & .087 \\
\hline $\begin{array}{l}\text { Private institutes } \\
.950\end{array}$ & 450 & 2.70 & .0102 \\
$\begin{array}{l}\text { Public schools } \\
.684\end{array}$ & 889 & 1.90 & \\
\hline
\end{tabular}

Table 7.1. Independent t-test results

\begin{tabular}{ccccccc}
\hline $\begin{array}{c}\mathrm{F} \\
\text { standard }\end{array}$ & Sig & $\mathrm{t}$ & $\begin{array}{c}\text { degree of } \\
\text { freedom }\end{array}$ & Sig. (2-tailed) & mean & \\
mean & & & & difference & error \\
\hline 8.842 & .003 & 5.124 & 1337 & $\mathbf{. 0 0 0}$ & .794 & .155 \\
\hline
\end{tabular}

From Table 8, the mean for instructional environment of private institutes $(\mathrm{M}=2.56)$ is higher than the mean for teacher employed in in public schools $(\mathrm{M}=1.91)$. It means that the instructional environments of private institutes are more effective. Therefore, independent sample t-test analysis (Table 8.1) shows that the difference between two public schools $(n=889, M=1.91, S D=.134)$ and private institutes $(n=450, M=2.56, S D=.125)$ contexts, in terms of instructional environment, is statistically significant, $\operatorname{Sig}=.000, \mathrm{p}>0.05$. 
Table 8. Descriptive statistics of "instructional environment" variable in public schools \& private institutes

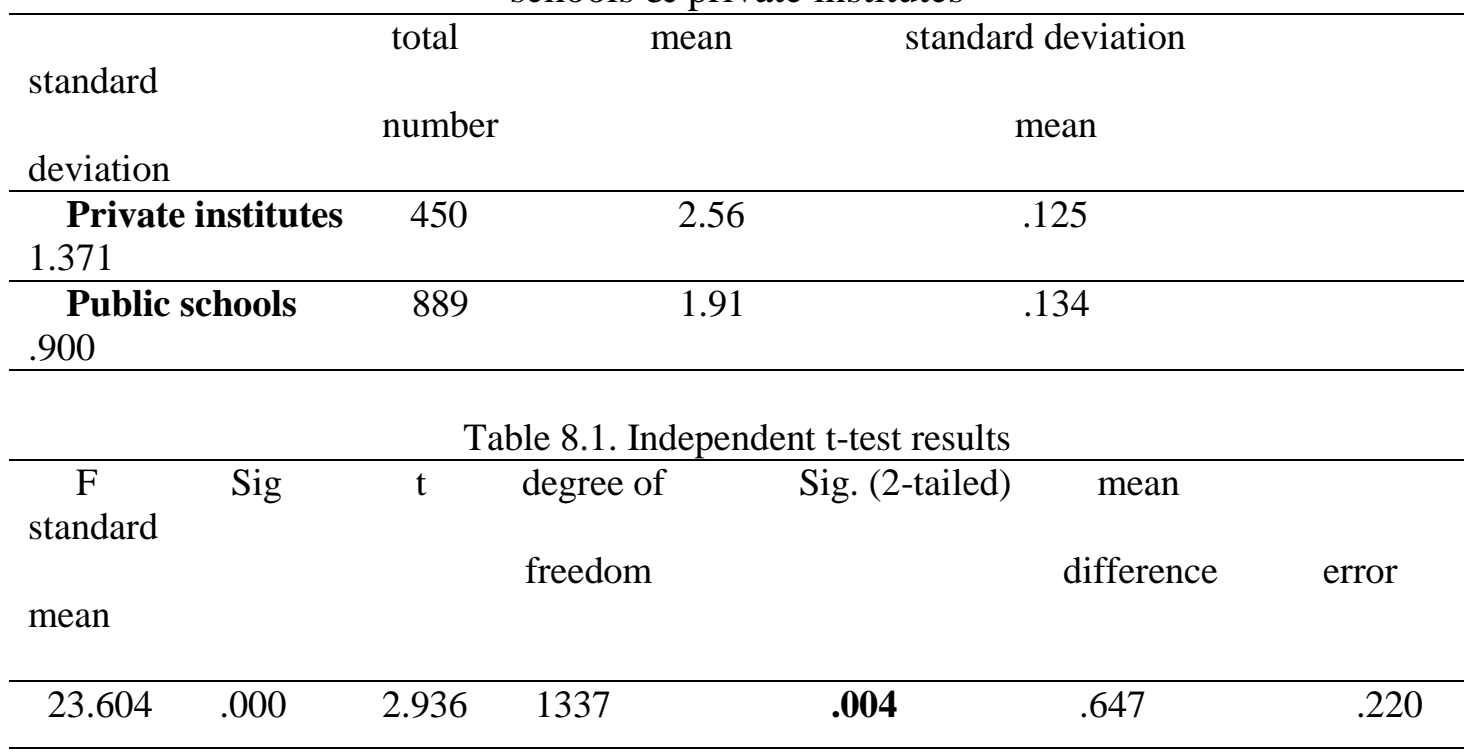

As it is shown in table 9.1, the p-value is more than $0.05(0.82>0.05)$ which indicates that there is no statistically significant difference between two public schools and private institutes contexts in terms of time. As a result, it can be consummated that the time variable cannot be considered an effective factor in learning English in two contexts. Then, according to the results, any incongruity between the effectiveness of two contexts may not be attributed to the amount of time devoted to the classes.

Table 9. Descriptive statistics of "time" variable in public schools \& private institutes

\begin{tabular}{lcccc}
\hline standard & total & mean & standard deviation & \\
deviation & number & & mean & \\
\hline Private institutes & 450 & 1.97 & .064 & .701 \\
\hline Public schools & 889 & 1.76 & .096 & .642 \\
\hline
\end{tabular}

Table 9.1. Independent t-test results

\begin{tabular}{ccccccc}
\hline $\mathrm{F}$ & Sig & $\mathrm{t}$ & $\begin{array}{c}\text { degree of } \\
\text { freedom }\end{array}$ & Sig. (2-tailed) & $\begin{array}{c}\text { mean } \\
\text { difference }\end{array}$ & $\begin{array}{c}\text { standard } \\
\text { error }\end{array}$ \\
mean & & & & & & \\
\hline 2.633 & .107 & 1.750 & 1337 & $\mathbf{. 0 8 2}$ & .210 & .120 \\
\hline
\end{tabular}

Regarding the results of the t-test for the "age" factor, table $10 \& 10.1$ suggest that there is not a statistically significant difference between two educational 
systems of public school and private institute in terms of age. Since $(\mathrm{P}=0 / 056)$, then, it can be concluded that age could not create significant change on the behavior of the learners in language proficiency development. But descriptive statistics of two educational systems show that the effect of age on oral proficiency in private institutes with a mean of 2.23 is higher than that of public schools with the mean of 1.78 .

Table 10. Descriptive statistics of "age" variable in public schools $\&$ private institutes

\begin{tabular}{lccc}
\hline standard & total & mean & standard deviation \\
number & & mean \\
deviation & num & & .131 \\
$\begin{array}{l}\text { Private institutes } \\
1.430\end{array}$ & 450 & 2.23 & .168 \\
$\begin{array}{l}\text { Public schools } \\
1.126\end{array}$ & 889 & 1.78 & \\
\hline
\end{tabular}

Table 10.1. Independent t-test results

\begin{tabular}{ccccccc}
\hline $\begin{array}{c}\mathrm{F} \\
\text { standard }\end{array}$ & Sig & $\mathrm{t}$ & $\begin{array}{c}\text { degree of } \\
\text { freedom }\end{array}$ & Sig. (2-tailed) & mean & \\
mean & & & & difference & error \\
\hline 9.367 & .003 & 1.923 & 1337 & $\mathbf{. 0 5 6}$ & .456 & .237 \\
\hline
\end{tabular}

According to the Table 11, the mean for "motivation" of the language learners of private institutes $(M=1.89)$ is relatively higher than the mean for "motivation" of the students of public schools $(M=1.70)$. It means that the motivation of the language learners of private institutes nay be attributed to their better oral proficiency. Then, independent sample t-test analysis (Table 11.1) shows that the difference between "motivation" variable across two public school $(n=889$, $M=1.70, S D=.093)$ and private institute $(n=450, M=1.89, S D=.080)$ contexts is not statistically significant, Sig $=.179, \mathrm{p}>0.05$. As a result, it can be concluded that the motivation variable cannot be considered an effective factor in oral proficiency in two contexts.

Table 11. Descriptive statistics of "motivation" variable in public schools \& private institutes

\begin{tabular}{lcccc}
\hline & $\begin{array}{c}\text { total } \\
\text { number }\end{array}$ & mean & $\begin{array}{c}\text { standard deviation } \\
\text { mean }\end{array}$ & $\begin{array}{c}\text { standard } \\
\text { deviation }\end{array}$ \\
\hline Private institutes & 450 & 1.89 & .080 & .873 \\
\hline Public schools & 889 & 1.70 & .093 & .625 \\
\hline
\end{tabular}


Table 11.1. Independent t-test results

\begin{tabular}{ccccccc}
\hline $\mathrm{F}$ & Sig & $\mathrm{t}$ & $\begin{array}{c}\text { degree of } \\
\text { freedom }\end{array}$ & Sig. (2-tailed) & $\begin{array}{c}\text { mean } \\
\text { difference }\end{array}$ & $\begin{array}{c}\text { standard } \\
\text { error mean }\end{array}$ \\
\hline 7.012 & .009 & 1.348 & 1337 & $\mathbf{. 1 7 9}$ & .192 & .142 \\
\hline
\end{tabular}

Independent sample t-test analysis (Table 12.1) shows that the difference between two public school $(n=889, M=1.86, S D=0.87)$ and private institute $(n=$ $450, M=2.23, S D=.058$ ) contexts, in terms of need of students, is statistically significant, Sig $=.001, \mathrm{p}>0.05$. Then, according to the results, any difference between the effectiveness of two contexts may be attributed to the needs of students.

Table 12. Descriptive statistics of "need" variable applied in public schools \& private institutes

\begin{tabular}{llcc}
\hline standard & total & mean & standard deviation \\
deviation & number & & mean \\
\hline $\begin{array}{l}\text { Private institutes } \\
.638\end{array}$ & 450 & 2.23 & .058 \\
\hline $\begin{array}{l}\text { Public schools } \\
.583\end{array}$ & 889 & 1.86 & .087 \\
\hline
\end{tabular}

Table 12.1. Independent t-test results

\begin{tabular}{ccccccc}
\hline F & Sig & $\mathrm{t}$ & $\begin{array}{c}\text { degree of } \\
\text { freedom }\end{array}$ & Sig. (2-tailed) & $\begin{array}{c}\text { mean } \\
\text { difference }\end{array}$ & $\begin{array}{c}\text { standard } \\
\text { error mean }\end{array}$ \\
\hline .513 & .475 & 3.436 & 1337 & $\mathbf{. 0 0 1}$ & .375 & .109 \\
\hline
\end{tabular}

According to the Tables $13 \& 13.1$, it can be concluded that the mean for "book" in private institutes $(\mathrm{M}=2.12)$ is higher than the mean in public schools $(\mathrm{M}=1.59)$. It means that the books used to teach English in private institutes are more efficient than the books prepared to achieve the purposes of public educational system. Consequently, according to the Table 13.1, the p-value is less than 0.05 (0.001>0.05) which indicates that there is a statistically significant difference between the effectiveness of books used in two contexts. As a result, it can be consummated that the two kinds of books were not relatively at the same level of effectiveness in two contexts. Then, any incongruity between the speaking performance of two groups from public schools and private institutes may be attributed to the kind of books and instructional materials used in the classrooms. 
Table 13. Descriptive statistics of "book" variable in public schools \& private institutes

\begin{tabular}{lcccc}
\hline \multirow{2}{*}{$\begin{array}{l}\text { standard } \\
\text { total }\end{array}$} & mean & standard deviation & \\
deviation & number & & mean & \\
\hline Private institutes & 450 & 2.12 & .085 & .927 \\
\hline Public schools & 889 & 1.59 & .101 & .677 \\
\hline
\end{tabular}

Table 13.1. Independent t-test results

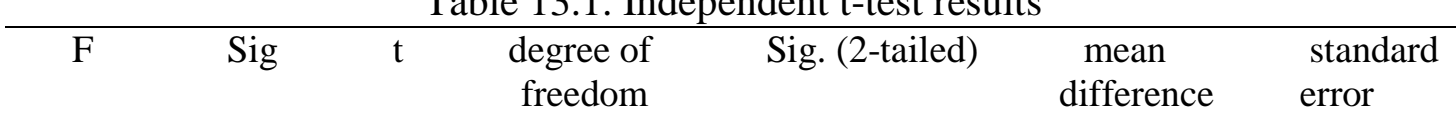

mean

\begin{tabular}{lllllll}
11.610 & .001 & 3.483 & 1337 & .001 & .528 & .152 \\
\hline
\end{tabular}

\section{CONCLUSION}

The main purpose of the current comparability study was to examine the obstacles that might cause the failure of either public schools or private institutes to apply communicative principles of language teaching in EFL in order to promote the speaking performance of language learners. The main addressed issues were related to the effectiveness difference of some factors to help language learners enhance their oral performance. The results of the study showed that Iranian students participated in the study emphasized on some factors and variables that might have effect on language learning and might lead to a better oral proficiency and practical use of English language in different situations. Since learning English through public education is the most important and cheapest way of learning in Iran, it attracted much attention in the past two decades. Some major but not enough reforms have been made in English teaching and learning in Iran in recent years. Following some recent reforms that were applied to the English course in public education, some macro-cities like Sari, Gorgan and Tehran started to teach English at the elementary levels of public schools. All the attention to English in public education and the current attempts to carry out more improvements indicate that the public English education lacks the efficiency to train competent English language users.

Based on the present research, the poor speaking performance of the students of public schools can be traced back into lack of some effective factors in the public educational system. Our research findings on the achievement in oral proficiency of language learners are compatible with the results of Safari and Rashidi (2015). They state that English Language teaching program in public educational system has failed to enhance the communicative abilities of students. In fact, the students who learned English in public schools are not able to use the language in authentic situations. They enumerate some reasons such as employing inappropriate textbooks 
and methods as well as mixed-level classes for the failure of public education to promote oral proficiency and long life communicative abilities of the students.

According to the findings, the method that is used in the classroom may have a great effect on the oral proficiency of language learners. In Iranian public schools, teaching English is mostly based on the principles of Grammar Translation Method. In English classes of public schools, teachers use the Persian as the first language of the students. The students have to read relatively long passages and memorize vocabularies. The small parts of speaking tasks are even used to explain the grammatical structures. It should be noted that although GTM is well-accepted by teachers of public schools, it has absolutely its negative effects on especially improving oral proficiency. The demotivating nature of GTM on language learners achievement was highlighted by Sahargard and Alimoradi (2013, p. 1). They enumerated some reasons of debilitative nature of GTM such as "lack of teachers" competence, lack of creative teaching styles, focus on English usage, lack of interest in English, teacher-centered classrooms and the focus of teaching".

Another factor that may be considered as an obstacle in public education to teach language is the language teachers. According to Breen and Candlin (1980) as cited in Kumaravadivelu (2006, p. 120), the teachers should be able to take three roles in the communicative classrooms. The teachers should be facilitators of the communicative process. Then, they should be able to play the role of the participants in the classrooms and observe the students (observers). Furthermore, Richards (2006) declared that the teachers should be familiar with both the target language and culture and use the language fluently and appropriately in the classrooms. Based on the findings of the present research, most of the Iranian teachers of public schools are not familiar with the culture of the target language because they cannot travel to the US, the UK or other English speaking countries in order to expand their experiences by familiarizing with the culture of these people. According to the present research findings which are in favor of Dahmaraeh (2009)'s findings, it can be concluded that most of the Iranian English language teachers are not qualified enough to implement the communicative principles of language teaching in their classrooms. Based on a part of interview data, it has been revealed that the majority of teachers in Iran have to work in several schools due to their low income. Then, they have not enough free time to be prepared for their classes.

In every educational system, there should be a balance to running an organized classroom. For example, too much structure that is set in place may block the creativity of the teacher and students. In another case, even not enough structure may cause distractions and little focus in the classroom. Then, the teachers have a difficult job to balance freedom and spontaneity with rules and guidelines. According to the results of the present study, it can be concluded that the instructional environment is an important factor that might have an impressive effect on the learning of English in a TEL program. The results show that private institutes enjoy more effective instructional environments that lead to better manipulating English. It was found that the teachers of private institutes implemented more engaging activities and tasks in the established classroom structure in order to achieve an encouraging and well-organized instructional environment. 
This comparability study was conducted in two ELT contexts of public school and private institute in Iran. From these two contexts, just public schools are funded and supervised by the Ministry of Education. Two completely different educational systems are employed for ELT program in these two contexts. Although, millions of Iranian students learned English in public schools through the instructions that are pre-determined and delivered by the Ministry of Education (government organization), their needs, expectations and current level of proficiency are not taken into account. According to Dahmardeh (2009), in public school, English subject matter for which textbooks, materials, and assessment system is planned by the Ministry of Education is compulsory in the curriculum of the educational system and the teachers are necessarily obliged to follow these predetermined requirements.

In ELT program, the selected topics should be related to the students' interests and needs. Regarding the nature of topics, it can be concluded that the students are more interested in working on the topics that are directly related to their reasons for learning English. In public educational system, the subjectively predetermined topics within the ELT program are based on what the authors thought might be appropriate for students. Therefore, there is no query about what the students of public schools might be interested in. Because the need of students are not satisfied in public schools, they prefer to enroll at private institutes in which the teachers and students worked on interesting topics and materials to promote their English proficiency, especially oral skills.

The findings of the current study are compatible with the findings of Moradi (1996) and Safari \& Rashidi (2015) who state that teaching and learning English in Iranian public schools has not been able to satisfy the specified goals. Then, due to different needs of language learners of private institutes to enhance their communicative abilities, they enroll at private institutes. Their principal purpose is to learn how to speak and how to improve their oral proficiency in order to use the language communicatively in real life situations.

Many education authorities such as the authors and program developers show tendency for more improvement in the teaching materials applied in Iranian public schools. The more attracting and appealing the materials, the better the results will be (Aliakbari, 2004). The diverse instructional materials used by private institutes are more attractive. Parents, teachers, and students expressed their preferences for the materials introduced by the private sector, although this does not mean that the materials currently used in public sector are useless or lack coherence. In fact, adding aesthetic aspects, diversifying the tasks and activities, and preparing work and test books, teacher manuals, SDs, videotapes, etc. would definitely improve results. The participants believed that holding seminars, material evaluation workshops, etc. would have little or no effect on addressing their real needs. According to the results of this survey, there are some benefits in ELT program in private institutes. It seems that the issue of providing the public schools with communicative methods, interesting books and attractive instructional materials, competent manpower familiar with the target language and culture, qualified assessment system should be taken into account seriously. It is clear that 
methodology, content of book, teacher, instructional environment, age, need, and other factors have effects on language learners' learning. What make the language learning easier and practical in private sector is that language learners practice with teachers and other students in the classroom. To have a language teacher who can answer the questions and correct the students' mistake indirectly in a practical way is important. Classmates are great sources of collaboration, practice, help, and motivation. The learners in private institutes collaborate with the teachers and classmates and are disciplined with language books, CDs, computers and other technological tools which may cause growing interest (Khoshsima \& Hashemi, 2017c) in better performance. They try to find native speakers of the target language who can help them practice conversations. Then, as the study suggests, the needs of language learners are different. The students of public schools study just to get the final score to pass the credit and it seems that they do not feel the need to study the language for communication and do not have enough motivation to study for such a goal.

The current research findings indicate that the educational system of private institutes enjoy more practical communicative methods, more experienced and competent teachers who are familiar with the target language and culture, wellorganized instructional environment and more encouraging instructional materials. In private institutes, the communicative needs of the learners are satisfied. Although more time was dedicated to more sessions in the private institutes, the difference between the amounts of dedicated times in two contexts was not statistically significant. Accordingly, based on the findings, the age and motivation factors were not considered as the factors that may have effect on the oral proficiency of Iranian language learners of intermediate level. Farooqui (2007) proposes that communicative methods should be used in all classes in order to provide the students with the opportunities to interact each other. This is because the emphasis, in language institutes, is on language in use rather than language as structure and the main purpose is to develop students' skills in English language and the focus is on the spoken form of English and oral proficiency, though reading, writing and listening skills are also focused on. Practice of pronunciation, stress and intonation is a vital component and language is based on real life situations. Hence, the students' communicative competence rather than linguistic competence is the objective. Then, in private institutes, the students are necessarily provided with skillful teachers who can handle the language classes in productive ways by applying effective communicative methods. These skillful teachers can also prepare language learners for the practical use of English in communication. Since they are all university graduates of English and pass specialty and training courses, they have a good knowledge of language and communicative methodologies. They have their own beliefs and conceptions about the process of teaching. Because the needs of language learners of private institutes are different from the needs of public schools' students (i.e. they want to use language communicatively in real life situations), the classroom materials and activities are often authentic to reflect real-life situations and demands. In private institutes where communicative methods are applied to teach language, all basic skills are integrated from the beginning; most of the given 
activities might involve reading, speaking, listening, and perhaps also writing. The teacher's role is primarily to facilitate communication and only secondarily to correct errors and the teacher should be able to use the target language fluently and appropriately.

Based on the findings of the present study, some constraints are responsible for the success or failure of each ELT program applied in two public school and private institute contexts. The failure of the ELT program applied in public educational system can be summarized in type of teaching methodology (mostly used GTM), incompetent teachers, textbooks, assessment system, and so on. Due to the lack of efficiency of the ELT program applied in public schools, the current ELT program should be carefully studied more in terms of the features mentioned in this research. This research tried to explore the problems and challenges of two educational systems applied in both public and private sectors. The obtained results help policy makers and governmental bodies disentangle the problems associated with the failure of public ELT program. Doing so will absolutely help the Iranian students promote their long life communicative language skills and competency.

\section{REFERENCES}

Abu Ghararah, A. (1998). Teaching English as a Foreign Language. Riyadh: Tawbah Library.

Alam Q., Bashir Uddin, A. (2013). Improving English Oral Communication Skills of Pakistan Public School's Students. International Journal of English Teaching, Vol.1, No 2, pp. 17.36, December 2013.

Aliakbari, M. (2004). The place of culture in the Iranian ELT textbooks in high school level. Paper presented at the 9th Pan-Pacific Association of Applied Linguistics Conference. Namseoul University, Korea.

Ary, D., Jacobs, L.C., \& Sorenson, C. (2010). Introduction to Research Education (8th Ed.) New York, NY: Wadsworth.

Atai, M.R., \& Mazlum, F. (2013). English language teaching curriculum in Iran: Planning and practice. The Curriculum Journal, 24(3), 389-411. https://doi.org/10.1080/09585176.2012.744327.

Bahrani, T \& Shu Sim, T. (2012). Informal Language Learning Setting: Technology or Social Interaction?. The Turkish Online Journal of Educational Technology- April 2012, Volume 11 issue 2.

Breen, M. P., \& Candlin, C. N. (1980). The essentials of a communicative curriculum in language teaching. Applied Linguistics, 1(2), 89-110. https://doi.org/10.1093/applin/1.2.89

Brown, H. D. (2000). Principles of language learning and teaching. San Francisco: Addison Wesley Longman, Inc.

Burns A, Joyce H (1997). Focus on Speaking. Sydney: National Centre for English. Language Teaching and Research. Retrieved January 12, 2012, from education.arts.unsw.edu.au/staff/anne-burns-1097.html. 
Brown, G., \&Yule, G. (1983). Teaching the spoken language. Cambridge: Cambridge University Press.

Cotter, M. (2007). The influence and effects of discriminatory language in New Zealand. The International Journal of Language, Culture and Society, 22, 5256. Retrieved from http://www.educ.utas.edu.au/users/tle/JOURNAL/issues/2007/22.6.pdf.

Crystal, D. (2003). A dictionary of linguistics and phonetics. Malden, MA: Blackwell.

Dahmardeh, M. (2009). English language teaching in Iran and communicative language teaching. A thesis for the degree of Doctor of Philosophy in education .The university of Warwick.

Dronkers, J. (2001). More Parental Choice in Europ? Overview of Effectiveness Differences between Religious Schools and Public Schools in several European Societies. Paper presented at the annual.

Ellis, G. (1996). How culturally appropriate is the communicative approach? ELT Journal, 50(3), 213-218. https://doi.org/10.1093/elt/50.3.213.

Farooqui, S. (2007). Developing speaking skills of adult learners in private universities in Bangladesh: problems and solutions. Australian Journal of Adult Learning, (47), $1-15$.

Fowler, W., \& Coe, N. (1976). Nelson English Language Tests. Melbourne: Thomas Nelson and Sons Ltd.

Ghorbani, M.R. (2009). ELT in Iranian high schools in Iran, Malaysia and Japan. Reflections on English Language Teaching, 8(2), 131-139.

Gutierrez, M. Junkal. (2005). the acquisition of English LD wh-questions by Basque/Spanish bilingual subjects in a school context. Doctoral dissertation, University of the Basque Country.

Hashemi Toroujeni, S.M. (2016). Computer-Based Language Testing versus Paperand-Pencil Testing: Comparing Mode Effects of Two Versions of General English Vocabulary Test on Chabahar Maritime University ESP Students' Performance. Unpublished thesis submitted for the degree of Master of Art in Teaching. Chabahar Marine and Maritime University (Iran).

Hughes, R. (2011) Teaching and researching speaking. 2nd edition. Harlow: Longman.

Hughes, A. (2003).Testing for Language Teachers. Cambridge: Cambridge University Press.

Hofman, R. H. (1993). Effectief schoolbestuur. Een studie naar de bijdrage van schoolbesturen aan de effectiviteit van basisscholen. [Effective school administration. A study on the contributions of school boards to school effectiveness]. Groningen: RION.

Kavaliauskiene, G. 2006. Good Practice in Teaching ESP Presentations. ESP World. Vol. 5, Issue 2(13).

Khoshsima, H. \& Hashemi Toroujeni, S.M. (2017). Transitioning to an Alternative Assessment: Computer-Based Testing and Key Factors related to Testing Mode. European Journal of English Language Teaching, Vol 2, Issue 1 (2017). http://dx.doi.org/10.5281/zenodo.268576. 
Khoshsima, H., Hosseini, M. \& Hashemi Toroujeni, S.M. (2017). Cross-Mode Comparability of Computer-Based Testing (CBT) versus Paper and PencilBased Testing (PPT): An Investigation of Testing Administration Mode among Iranian Intermediate EFL learners. English Language Teaching, Vol 10, No 2(2017). http://dx.doi.org/10.5539/elt.v10n2p23.

Kumaravadivelu, B. (2006). Understanding language teaching: From method to post-method. Laurence Erlbaum Associates, Publishers.

Khoshsima, H., \& Izadi, M. (2015a). Creativity in Writing: A Study of EFL Learners' Locus of Control. International Journal of Applied Linguistics \& English Literature, Vol. 4 No. 2; March 2015. URL: http://dx.doi.org/10.7575/aiac.ijalel.v.4n.2p.8.

Khoshsima, H., \& Roostami, A. A., \& Afiati, L. (2015b). English and Non-English Major Teachers; Assessment of Oral Proficiency: A Case of Iranian English Learners. Iranian Journal of English for Academic Purposes (IJEAP), Vol. 1 No. 4, 76-87.

Merriam, S. B., (2002). Qualitative Research in Practice: Examples for Discussion and Analysis. San Francisco: Jossey-Bass, 2002.

Moradi, F. (1996). An Investigation into the Problems of Teaching \& Learning English in Tehran Province. Unpublished M. A. Thesis, Shiraz University, Shiraz.

Nazara, S. (2011). Students' Perception on EFL Speaking Skill Development. Journal of English teaching

Nunan, D., \& Bailey, K.M. (2009). Exploring second language classroom research. Boston: Heinle.

Pishghadam, R., \& Saboori F. (2011). A qualitative analysis of ELT in the language institutes of Iran in the light of the theory of World Englishese. Journal of Language Teaching and Research, 2(3), 569-579. https://doi.org/10.4304/jltr.2.3.569-579.

Richards, J. C. (2006). Communicative Language Teaching Today. New York: Cambridge University Press.

Safari, P., \& Rashidi, N. (2015). A critical look at the EFL education and the challenges faced by Iranian teachers in the educational system. International Journal of Progressive Education, 11 (2), 14-28.

Scheerens, J. \& Bosker, R. (1997). The Foundations of Educational Effectiveness. Kidlington/New York/Toyko: Pergamon.

Schofield, P. J. \& Gitsaki. (1996). What is the advantage of Private School Instruction? The Example of English Vocabulary Learning in Greece. System, 24 (1), 117- 127. https://doi.org/10.1016/0346-251X(95)00057-Q.

Sharabian, Sh., Kheierabadi, Reza, Alavi Moghaddam, S. Behnam, Anani Sarab, Mohammad Reza, Forouzandeh Shahraki, Elham, \& Ghorbani, N. (2013). English for Schools: Prospect 1. Tehran: Iran's School Book Publishers.

Sahragard, R., \& Alimorad, Z. (2013). Demotivating factors affecting Iranian high school students' English learning. Retrieved June 05, 2015 from http://works.bepress.com/zahra_alimorad/6. 
Taylor, B. P. (1983). Teaching ESL: Incorporating a communicative, studentscentered component. TESOL Quarterly, 17(1), 69-85. https://doi.org/10.2307/3586425.

Teddlie, C \& Reynolds, D. (2000). The international handbook of school effectiveness research. London: Falmer.

Warner, R. M. (2013). Applied Statistics: From Bivariate through Multivariate Techniques. (2th Ed.). SUA: SAGE Publication Inc.

Zare Behtash, E., Hashemi Toroujeni, S.M. \& Safarzade Samani, F. (2017). An Introduction to the Medieval English: the Historical and Literary Context, Traces of Church and Philosophical Movements in the Literature. Advances in Language and Literary Studies, Vol. 8, No. 1; February 2017. Doi:10.7575/aiac.alls.v.8n.1p.143. URL:

http://dx.doi.org/10.7575/aiac.alls.v.8n.1p.143.

Author:

Hooshang Khoshsima, Ph.D. Associate Professor

English Language Department

Faculty of Management and Humanities

Chabahar Maritime University, Chabahar, Iran

Khoshsima2002@yahoo.com

+989121097812

\section{Seyyed Morteza Hashemi Toroujeni, M.A. Candidate}

English Language Department

Faculty of Management and Humanities

Chabahar Maritime University, Chabahar, Iran

Hashemi.seyyedmorteza@gmail.com

M.hashemi@cmu.ac.ir 